\title{
THE HISTORICAL NOVEL
}

\author{
Sylvia Townsend Warner
}

(Lecture to the Third Congress of the League of American Writers from Fighting Words ed. Stewart, Donald Ogden; Harcourt Brace \& Co 1940)

When I was young I read everything in the house, including historical novels, and two things struck me. First, that historical novels had usually long and frequent descriptions of scenery - I supposed in order that the author might have a spell of taking it easy. Oaks and brooks get along through the centuries without much fuss about being 'period.' Second, that the period quality of the characters in these novels was a class distinction. The upper class characters were fully period. But the servants and the peasants and the social what-not had scarcely a period rag to cover them, except for an occasional 'zounds' or 'gadzooks,' and getting into a morris dance every now and then. They belonged to the date of the author.

This period class distinction has pretty good authority. It is the method of Shakespeare.

And I think you will agree with me that in almost every piece of historical fiction it is the characters of the ruled that come bursting out of the texture. But the reason for this class distinction? There are three reasons which might be put forward. First (and we can dismiss it forthwith), that the author wasn't going to bother with such small fry. He was too aristocratic. Second, that authors of historical novels are all near-Marxists, and were expressing the view that the closer you are to the economic, bony structure, the hungrier you are and the harder you work, the more permanent are your class characteristics; or, to put it another way, it is only the rich who 
can afford to be up to date, who can display strong period characteristics, whereas the poor get along with the minimum of fashion.

The third reason, which seems to me the likeliest, is this: if you examine the historical novel you will find that it is the working-class characters who fill the role of the commentator, the analyst, the person who sums things up. The noble sentiments, the villainous sentiments, go into the mouths of the ruling characters; but when it comes to a piece of plain common sense, it is the ruled who speak. So I would suggest that the authors kept their working-class characters contemporary because of this structural function of pinning the story together by comment and analysis; or, if you prefer, of keeping it from going bad by salting it. A wise word in the mouth of a lifeless character is no longer a wise word; it is just a moral maxim; and these commenting characters were kept contemporary because writers felt it the safest way in keeping them life-like.

All this, of course, applies to the traditional historical novel. More recently there has been a revolt against this, and all the characters in historical novels are of the present day, contemporary in speech, in behavior, in motive, in psychology. But the talisman is not infallible, and these characters straight out of modern life may make up a perfectly lifeless book. There must, it seems, be some recognition, of history in the historical novel. The writer of the historical novel cannot escape the obligation of a period.

We can cast 'gadzooks' and 'by our lady' behind us. They mean nothing. It is not the manner of speech that matters; but the matter of the speech, plus, - and this is crucial - the manner of the thinking. In all ages, the prime motives are the same; fear, love, anger, hunger, necessity, ambition - the old gang. Nor has the economic structure altered that much. To get some work to get enough to eat to get some work - it is a song of the ages. And the reactions to the economic structure are pretty constant too; but constant with a qualification. There were strong men before Agamemnon. There were tolerable Marxists before Marx. But they were before Marx. And an historical novelist who includes (and I think the 
historical novelist should) the economic ground-base, must simultaneously recognize the social-economic variations which move above that ground-base. Thomas More and Latimer, for instance, wrote as socialists; but they were Christian socialists. Oliver Cromwell had the career of a fascist leader; but he was a fascist before imperialism (though not before possibilities of European empires, as you can read in Marvell's 'Horatian Ode').

The historical novelist cannot dodge the obligation, so it seems to me, of knowing pretty accurately how people clothed their minds. Human nature does not change, etc., but human thinking alters a great deal, is conditioned by what it has been taught, what it believes, or disbelieves; what it admires in art or nature; at what age it marries; to what extent it has outwitted weather (it was the medieval winters, cold, dark, and boring, that taught the troubadours to praise the spring); what careers are open to it; whether it reads Aristotle or Plato; whether it believes in witches or planets. If you know these things, then you may have a chance of knowing all your characters, that is to say, a chance of making them life-like, or bringing the whole of your book to life.

And to do this there is nothing for it, I think, but to be historian enough to do a little research. There is no need to haunt museums, in fact it is sometimes better not to haunt museum's. You may not be able to see the showcases for the other historical novelists. And finally, after you have gathered your material, use a fruit-press. It's the juices you want. 